\title{
Economic Capacity as an Indicator of Sustainable Socioeconomic Efficiency of a Business Entity
}

\author{
Marina Astakhova*, Irina Ignatova \\ Institute for State and Law, University of Tyumen, Tyumen, Russia \\ *Corresponding author. Email: ast-marina@yandex.ru

\begin{abstract}
The modern global economy is developing in line with socialization and sustainable development. The operation of business entities in such an economic environment poses the challenge of finding the best tools for assessing their efficiency because of the inadequacy of traditional assessment tools for parameters of sustainable development. This paper proposes a new indicator for assessing the sustainable socioeconomic efficiency of a business entity in the light of the United Nations Sustainable Development Agenda 2030. The theoretical basis of the study are concepts of socioeconomic efficiency and measures of its assessing, income theories. The study uses methods such as a system testing method based on the black box model, a method for generating gross domestic product by the source of income, that adapts to the level of a business entity, and a method of constructing an aggregated indicator based on such baselines as the net income of a business entity, and the average number of employees. The main result of the study is the economic capacity indicator, which could be used at the micro level to assess business entities for socioeconomic efficiency in the realities of sustainable development.
\end{abstract}

Keywords: sustainable development, socioeconomic efficiency, an indicator of socioeconomic efficiency, assessment tools, economic capacity indicator

\section{INTRODUCTION}

The category of socioeconomic efficiency has received widespread coverage in sociological and economic theories from the various perspectives $[1 ; 2 ; 3 ; 4 ; 5 ; 6 ; 7 ; 8]$. In terms of content, the basis of this category form two aspects - social and economic. The social aspect refers to the extent to which social needs are met through economic activity, while the economic aspect relates to meeting the needs of the economic plan. By assessing socioeconomic efficiency, it is possible to understand the rational use of available material, labor, monetary and natural resources in the process of achieving the planned social and economic goals.

The assessment of socioeconomic efficiency is carried out using various indicators. As practice shows, the arsenal of such indicators varies depending on the level of the economy. Thus, at the macroeconomic level, the indicators of national income, gross domestic product, economic well-being, human development indices, global competitiveness, world development indicators of the World Bank, international happiness index are applied. The microeconomic level determines the use of other means. Therefore, microeconomic efficiency is measured by indicators of income, profit, cost, productivity, and profitability. Social efficiency at the micro-level is assessed through the prism of indicators of salary, number of employees, staff turnover coefficient.

In the light of the UN Agenda for Sustainable Development 2030, which determines the need to form a socially - oriented market economy, the issue of assessing socioeconomic efficiency is gaining a new sound. In other socioeconomic realities, many established indicators are losing their significance. In particular, the indicator of gross domestic product, a long time considered the gold standard for assessing the economic well-being of countries, has recently been actively criticized because of the inadequacy of the ideology of sustainable development. Many researchers believe that this indicator does not provide a full assessment, in the environment of a sustainable economy since it does not take into consideration such parameters as changes in the well-being of the population, the social consequences of the economic activity of business entities, the destruction of the natural environment and much more $[9 ; 10 ; 11]$. 
For example, Stieglitz and his colleagues believe that the gross domestic product indicator measures the dynamics of production, not well-being, and does not reflect social processes and changes in the environment that ensure sustainable development. The desire to achieve a high rate of growth in the gross domestic product may lead to deterioration in the quality of life of the population [12]. According to Flerbe, the gross domestic product does not reflect the social and environmental aspects of social development [13].

In addition to gross domestic product, other socioeconomic indicators are also critically assessed. So, Grishin and co-authors put forward the thesis that the human development index is eclectic, which makes it difficult to interpret data and compare by country and region [14]. Scientists believe that traditional macroeconomic indicators are unable to fully meet the goals set in the field of sustainable development [15].

The inadequacy of existing socioeconomic assessment tools encourages the search for alternatives that address trends in sustainable economic development. Such a task is directly set at the international level. As noted in chapter 40 of Agenda 21, adopted at the United Nations Conference on Environment and Development in Rio de Janeiro in 1992: "Sustainable development indicators should be developed to provide a sound basis for decision-making at all levels and to facilitate the selfregulatory sustainability of integrated environmental and development systems".

Currently, the development of such indicators is being actively pursued at various levels. To date the system of indicators of sustainable development (UN Commission on Sustainable Development), the system of integrated environmental and economic national accounts (UN Statistics Division), the indicator of "true savings" (World Bank), environmental indicators (Organization for Economic Cooperation and Development) have been developed [16].

In the light of the above, another conceptual attempt to create sustainable socioeconomic indicators seems quite justified. At the same time, it should be noted that the present study proposes an indicator of the microeconomic level, which could be used as a tool to assess the socioeconomic efficiency of a business entity operating in a socially-oriented economy. When developing this indicator, we applied an alternative approach to assessing the social role of a business entity in terms of income distribution. We consider a business entity as an economic system that serves as a source of income for three subjects of society: the enterprise itself, society, and the state. This positioning is possible due to the adaptation of the income calculation method used in calculating the gross domestic product (macro-level) to the enterprise level (micro-level). The dynamics of economic capacity can demonstrate the sustainability of the development of a business entity, and, therefore, its socioeconomic efficiency. The results of the study can serve as a theoretical basis for developing conceptual models for the sustainable development of business entities in a social state.

\section{MATERIALS AND METHODS}

To create the economic capacity indicator, we used the original author's methodology, which includes several research stages. In the first stage, a business entity is positioned as an economic system and tested using the black box method, which allows distinguishing certain input and output parameters. One of the output parameters is the income of a business entity. Subsequently, it receives a special interpretation, and in the interpreted form is used as a component of the formula of the economic capacity indicator. In the second stage, the need for an alternative to business entity income as an indicator of its efficiency is justified. The reason for this need is the revealed inconsistency of this indicator with the requirements of a sustainable social economy. In the third stage, a list of the baselines used to construct the economic capacity indicator is determined.

\subsection{A Business Entity as an Economic System. Testing a Business Entity as an Economic System by the Black Box Method}

To create a theoretical and instrumental basis for calculating the economic capacity indicator, we first positioned a business entity as an economic system, and tested it using the black box method. By black box it is accepted to mean a system whose internal device and mechanism of operation are very complex, unknown, or not important within the framework of this task [17]. The system, represented as a black box, is considered to have a certain input for the input of source resources and output for output of results. The processes taking place in the operation of the system are unknown to the observer. At the same time, it is assumed that the output state is functionally dependent on the input state.

Structurally, any system is a set of elements that form a certain unity and integrity through stable relationships and linkages between the elements in the interior of the system. In this regard, the economic system can be defined as a set of interrelated elements that define the unity and integrity of relations in the production, distribution, exchange, and consumption of economic benefits. From the point of view of the actors of such relations, the economic system is essentially any economic entity: a country, a region of a country, a business entity. In turn, any business entity, through a complex internal organizational and property structure and the interconnectedness of elements, can also be recognized by the system.

To position a business entity as a system we used the model of black box proposed by Eshby [17]. For a 
business entity, the black box model is as follows. At the input into the system, such factors of production as labor, land, capital, entrepreneurial resource come from the external environment. At the output, the external environment receives a product (goods, jobs, services), income, and other results. In the process of constructing the economic capacity indicator, we will focus on an output parameter such as income.

\subsection{Need for an Alternative to Income as an Assessment Tool of a Business Entity Performance}

In the economic theory, income is traditionally considered as the monetary amount that a business entity receives as a result of its activities, excluding material and related expenses. Income generation in the market economy is assessed as the main goal of a business entity, and the size of this income is estimated as one of the main indicators of economic efficiency. This is due that income is the most important factor in stimulating productive activities, creating a financial basis for expanding production, as well as for meeting the social needs of staff.

As an economic system operating in a market economy, a business entity initially accumulates various factors of production at the input. Further, it converts these factors into its internal environment, resulting in various outputs, including income. Income generation is the main goal of a business entity, which in turn is its sole recipient. In this case, the amount of income demonstrates the degree of satisfaction of a business entity's interests.

In the social economy, the value of a business entity's income seems different. The concept of the social economy determines the primary goal of economic activity to satisfy social interests, thereby putting the interests of people and society above the interests of capital $[18 ; 19 ; 20]$

According to this thesis, a business entity, as an economic system in a social state, must transform the factors of production in such a way as to obtain a product that satisfies not only its interests but, above all, the interests of society and the state. Obtaining income without taking public interests and requirements for the quality of products in a social state does not guarantee the sustainability of a business entity. This is due to that sustainability will be ensured if a business entity exists and develops, which in turn depends on its social contribution. Consequently, in a social state, any business entity bears a social burden. This confirms the importance of the principle of the satisfaction of private interests through the satisfaction of the public interest. Thus, while the priority goal of a business entity is to generate income, its achievement is directly related to the implementation of the social goal.
The external goal of a business entity as a socially oriented economic system is to socialize the identified social needs. In such circumstances, a business entity must transform the elements of the environment into a result that meets the requirements of society. Thus, the main task of a business entity is to determine the social needs that provide long-term prospects for the existence of a business entity, and their satisfaction. The internal goal of a business entity is to generate income. It is achieved by meeting public needs. A business entity must produce a product of a quality that meets public needs. This will allow a business entity to best meet its private needs. Hence, income generation cannot be the main goal of a business entity interested in sustainability and development. On the contrary, if the maximizing income at all costs becomes the main goal of a business entity, this will lead to the depletion of natural resources, environmental catastrophe, low level of satisfaction of public needs, instability, stagnation, etc. Thus, in the context of the social economy, economic systems, and in particular business entities, should serve as a tool of meeting social needs.

Because of the above, the income of a business entity in its traditional sense cannot be considered as a fullfledged tool of assessing efficiency in the social economy, since it reflects the economic interests of only one actor. On the contrary, an assessment tool that simultaneously reflects the social and economic interests of a business entity, society, and the state will be optimal. As one of these possible tools we suggest using the economic capacity indicator.

\subsection{Baselines for Economic Capacity Indicator}

In the context of this study, an indicator means a rate that is derived from primary data and serves as a tool for assessing the status of a business entity as an economic system. The analysis of the practice of designing indicators of socioeconomic efficiency in the context of sustainable development demonstrates two methodological approaches. According to the first, separate indicators are formed to assess the economic and social aspects, which are subsequently combined into one indicator. The second approach involves the creation of aggregated indicators, which include various types of baselines: economic, social, etc. In the process of creating the economic capacity indicator, we used the second approach, according to which two baselines are used. The first baseline - net income of a business entity, and the second baseline - the average number of employees.

When developing the net income of a business entity, we were guided by the following theoretical ideas. In the economic theory, the category income has different interpretations. Thus, according to the theory of income distribution, primary income includes profits, rents, and wages related to the results of the activities of capitalists, 
landowners, and employees [21]. The theory of the three main factors of production identifies the income that workers receive in the form of wages and the remuneration received by the entrepreneur for abilities and talents [22]. According to the labor theory of value, the main source of income is labor [23]. In the theory of marginal productivity, society's income is divided into wages, interest, and profits, which in turn are earned for the performance of work, for the provision of capital, and the coordination of wages and interest [24]. Current income indicators adopted in the System of National Accounts (SNA) are based on the concept of income derived from the general equilibrium theory [25] and include three main types of income aggregated by domestic gross product: income, taxes, and wages.

Based on the results of applying the black box model in the process of testing a business entity as an economic system, income is positioned as one of the output results of a business entity, along with the product. To use the income of a business entity as one of the baselines of the economic capacity indicator we offer a special way of interpreting it. Its essence is to adapt the income method of calculating the gross domestic product to the level of a business entity.

The domestic gross product of the state through the prism of the income method is the sum of the income of society (as a combination of citizens of the state), business entities, and the state. The income of a business entity, considered in a similar perspective depending on the receiving actors, can be represented as the sum of the income of a business entity itself (net profit), state income (taxes), and social income (salary). Determining as agents of income-generating of a business entity not only a business entity itself but also the state and society allows concluding that a result of the functioning of a business entity, not only the economic effect for a business entity, but also the social effect for society and the state. For terminological differentiation, and, given that depreciation is ignored, the income of a business entity will be hereinafter referred to as the net income of a business entity.

The average number of employees reflects the number of employees of a business entity over some time (quarter, half-year, year). This baseline is traditionally used to calculate productivity, average wages, turnover, stability of employees, etc. We use it as an element of the formula for calculating the economic capacity indicator

\section{RESULTS AND DISCUSSION}

The construction of the economic capacity indicator is carried out in two stages. At the first stage, the net income of a business entity is calculated. Its calculation is carried out according to the following formula:
$\mathbf{N I B E}=\mathbf{T}+\mathbf{W}+\mathbf{N P}$, where

NIBE - net income of a business entity

$\mathrm{T}$ - taxes

W - wage

NP - net profit

The second stage involves modeling economic capacity as an aggregated indicator according to the formula:

$\mathrm{ECBE}=\mathrm{NIBE} / \mathrm{ANE}$, where

ECBE - economic capacity of a business entity

NIBE - net income of a business entity

ANE - the average number of employees

The economic capacity indicator allows reflecting the amount of net income of a business entity per employee. For example, we calculated the economic capacity for several companies operating in the same industry (air transportation). For illustrative purposes, consider the international airlines' Delta Air Lines (USA), International Airlines Group (Spain), Aeroflot (Russia) (see Table 1.)

Table 1. Economic capacity for 2019 (thousand dollars)

\begin{tabular}{|l|c|c|c|}
\hline $\begin{array}{l}\text { Company } \\
\text { name }\end{array}$ & $\begin{array}{c}\text { Delta } \\
\text { Air } \\
\text { Lines }\end{array}$ & $\begin{array}{c}\text { International } \\
\text { Airlines Group }\end{array}$ & Aeroflot \\
\hline Taxes & $\begin{array}{c}1 \\
278631\end{array}$ & 560000 & 195819 \\
\hline Wage & $\begin{array}{c}10029 \\
792\end{array}$ & 4962000 & 624623 \\
\hline Net profit & $\begin{array}{c}4259 \\
423\end{array}$ & 1715000 & 73104 \\
\hline $\begin{array}{l}\text { Net income of } \\
\text { a business } \\
\text { entity }\end{array}$ & $\begin{array}{c}15567 \\
846\end{array}$ & 7237000 & 893546 \\
\hline $\begin{array}{l}\text { Average } \\
\text { number } \\
\text { employees }\end{array}$ & 90000 & 72268 & 21763 \\
\hline $\begin{array}{l}\text { Economic } \\
\text { capacity (per } \\
\mathbf{1} \text { person) }\end{array}$ & $\mathbf{1 7 3}$ & $\mathbf{1 0 0}$ & $\mathbf{4 1}$ \\
\hline
\end{tabular}

Let us now consider the structure of the economic capacity, which reflects the socioeconomic effect, on the example of the companies under study. The economic effect of the company's performance is reflected through profit. The social effect is reflected through taxes and wages (see table 2). 
Table 2. Structure of the social and economic effect of companies for $2019(\%)$

\begin{tabular}{|l|c|c|c|}
\hline $\begin{array}{c}\text { Company } \\
\text { name }\end{array}$ & $\begin{array}{c}\text { Delta } \\
\text { Air } \\
\text { Lines }\end{array}$ & $\begin{array}{c}\text { International } \\
\text { Airlines Group }\end{array}$ & Aeroflot \\
\hline \multicolumn{4}{|c|}{ The social effect } \\
\hline Taxes & 8 & 8 & 22 \\
\hline Wage & 64 & 69 & 70 \\
\hline $\begin{array}{c}\text { Total social } \\
\text { effect }\end{array}$ & 72 & 77 & 92 \\
\hline \multicolumn{4}{|c|}{ The economic effect } \\
\hline Net profit & 28 & 23 & 8 \\
\hline $\begin{array}{c}\text { Total } \\
\text { economic } \\
\text { effect }\end{array}$ & 28 & 23 & 8 \\
\hline $\begin{array}{c}\text { Total net } \\
\text { income }\end{array}$ & 100 & 100 & 100 \\
\hline
\end{tabular}

According to Table 2, the overall social effect in the companies under study is high. However, there is an imbalance between the economic and social impact of business entities. The economic effect reflects net profit. Its share in Aeroflot is only $8 \%$. In Delta Air Lines and International Airlines Group, at the level of $8 \%$, the share of taxes that are included in the structure of the social effect. The share of wages is predominant for all three companies.

The economic capacity indicator shows the socioeconomic efficiency of a business entity per employee. We propose to use this indicator to assess the performance of business entities operating in a social economy to determine their sustainability. The market economy traditionally uses the income indicator, which reflects the economic efficiency. The contrasting of income and economic capacity indicators does not seem appropriate because they are different and reflect heterogeneous aspects of business entities. The amount of income reflects the economic efficiency of a business entity, and the economic capacity shows the socioeconomic contribution of each employee to the development of society.

\section{CONCLUSION}

The purpose of the present study was to propose the economic capacity indicator as a possible new indicator of sustainable development of business entities and to justify its use in assessing the socioeconomic efficiency and sustainable development in a social state. The stated goal was set due to the existing assessment tools do not fully ensure the possibility of assessing the effectiveness of enterprises in the context of the formation of the social economy. Most of these tools do not include such a sustainable development parameter as the social impact of economic activities of business entities.

To construct the economic capacity indicator, we followed several interlinked stages. During the first stage, a conditional definition of a business entity as an economic system was made, and its testing was carried out using the black box method. The applied approach made it possible to distinguish the income of a business entity as one of the output parameters. This parameter was subsequently subjected to interpretation, and in its interpreted form was used as a basis for calculating the economic capacity indicator. At the next stage, we justified the importance of finding an alternative to the income of a business entity as an indicator of its effectiveness due to the inadequacy of the realities of a sustainable social economy. The final stage was the definition of the baselines used in the calculation formula of the economic capacity indicator, which includes the net income of a business entity specially modeled by the authors and the average number of employees. The main process of creating economic capacity was the procedure for constructing an aggregated indicator, which is the ratio of net income of a business entity and the average number of employees. For illustrative purposes, the application of the economic capacity indicator to three companies operating in the air transport industry was demonstrated.

To test the economic capacity indicator in dynamics by industry, we plan to continue the study. In the future, we plan cross-sectoral comparisons at the international level. For a more accurate and objective assessment of sustainable development based on the economic capacity indicator, it is advisable to form time series in at least 10 years. This will allow us to track changes over a long time, identify cyclic fluctuations, investigate their factors, as well as the reasons for the deviation of this course and the intervals of fluctuations. The detailed analysis will contribute to the development of strategic patterns of behavior for business entities.

\section{FUNDING}

The reported study was funded by RFBR, project number 20-010-00996.

\section{REFERENCES}

[1] V. Pareto, Compendium on General Sociology, HSE, 2008.

[2] A. Etzioni, Toward a New Socio-Economic Paradigm, Socio-Economic Review 1 (2003) pp. 105-118. https://ssrn.com/abstract=2157130.

[3] J. Hollingsworth, Advancing the Socio-Economic Paradigm with Institutional Analysis. SocioEconomic Review 1 (2003) pp. 130-134. DOI: https://doi.org/10.1093/soceco/1.1.130.

[4] F. Fukuyama, Trust. The Social Virtues and the Creation of Prosperity, AST, 2004. 
[5] D. Davydyanc, Criterion, indicators, and evaluation of socio-economic effectiveness, Statistical issues 8 (2002) pp. 73-78.

[6] L. Isaeva. Economic and social effects in the reproductive process, Vestnik VGU. Series: Economics and Management. 1 (2012) pp. 32-37.

[7] V. Kolodijchuk., I.Kolodijchuk, Socio-economic aspects of the effectiveness category, Universum: Economics and Law, 13(2) (2015) pp.1-12. www./7universum.com/ru/economy/archive/item/1 900 .

[8] M. Buzmakova, Economic efficiency: the social dimension of the problem, Innovation and investment, 8 (2019) pp. 32-37.

[9] V. Molokanov, Problems of using the GDP as an indicator of the socio-economic development of society, Management issues, 60(5) (2019) pp. 178188

[10] T. Sidorina, Multiple approaches to the typology of the welfare state, Economics, 8 (2014) pp. 122 139. DOI: https://doi.org/10.32609/0042-87362014-8-122-139.

[11] I. Pavlova, I. Gumennikov, E. Monastyrnyj, D. Sharma, What is behind the integral indices of wellbeing? Bulletin of Science of Siberia. 31(4) (2018) pp. 230-254.

[12] D. Stiglic, A.Sen, Zh. Fitussi, Misjudging our lives. Why does GDP not make sense? Moscow: Gaidar Institute Publishing House, 2016.

[13] M. Flerbe, Beyond GDP: in search of a measure of public welfare, Economic issues, 3 (2012) pp. 3251. DOI: https://doi.org/10.32609/0042-8736-20123-32-51.

[14] V. Grishin, E. Ustyuzhanina, I.Komarova, GDP as an indicator of socioeconomic development: problems of measurement and use, Russian economic journal, 4 (2018) pp. 34-48.

[15] S. Bobylev, N. Zubarevich, S. Solovyova, The challenges of the crisis: how to measure the sustainability of development?, Economics, 1 (2015) pp. $147 \quad-\quad 160 . \quad$ DOI: https://doi.org/10.32609/0042-8736-2015-1.

[16] N. Tarasova, E. Kruchina Sustainable development indices and indicators, in N.P. Laverov (Eds.), Sustainable development: resourses of Russia, M: Izdatel'skij centr RHTU im. D.I. Mendeleeva, 2004, pp. 43-76.

[17] U. Eshbi, An introduction to cybernetics, J. Wiley, 1956.
[18] C.Walton, Corporate social responsibilities, Wads worth, 1967.

[19] A. Berle, G. Means, The Modern Corporation and Private Property. Harcourt, Brace and World, 1967. https://www.repository.law.indiana.edu/ilj

[20] H. Bowen, Social Responsibilities of the Businessman, Harper, 1953. DOI: https://doi.org/10.2307/j.ctt20q1w8f.

[21] A. Smit, An Inquiry into the Nature and Causes of the Wealth of Nations, Exmo, 2009.

[22] J. Say, A Treatise on Political Economy; or the Production, Distribution and Consumption of Wealth, Lippincott, Grambo \& Co, 1855. http://oll.libertyfund.org/people/jean-baptiste-say

[23] K. Marks, Capital A Critique of Political Economy, Eksmo, 2011.

[24] J. Clark, The Distribution of Wealth: A Theory of Wages, Interest and Profits, MacMillan, 1899. http://oll.libertyfund.org/titles/clark-thedistribution-of-wealth-a-theory-of-wages-interestand-profits.

[25] D. Hiks, Cost and capital, Progress, 1988. 